\title{
Subsurface waste management in the conditions of circular economy
}

\author{
Lyudmila Anatolyevna Mochalova *, and Olga Gennadievna Sokolova \\ Ural state mining University, Department of Economics and management, 620144, 30, Kuibyshev St., \\ Ekaterinburg, Russia
}

\begin{abstract}
The article is devoted to the consideration of modern approaches to the subsurface waste management and the integrated development of the mineral resources base, the development of which requires consideration of the environmental, industrial, technological and economic aspects of this issue. The authors of the article note that it is advisable to use such modern management technologies as circular business models, 3R and 5R concepts, as well as logistics methods of waste management for the waste management of enterprises of the mineral resources sector. These technologies make it possible to form an eco-industrial symbiosis, the main object of which is a mining enterprise connected with other symbiosis objects by material flows. The authors are convinced that the successful functioning of eco-industrial symbiosis will lead to the maximum use of subsurface waste, minimization of their storage and disposal volumes, and, ultimately, will contribute to the integrated use of mineral raw materials.
\end{abstract}

\section{Introduction}

Recently, the idea of a circular economy focused on the formation of a business system on the principle of "resources obtaining - products manufacturing - waste reuse/recycling" has grown significantly. Essentially, circular economy is a production and economic system that is closed in design and structure and based on the use of non-waste technologies [1]. Thus, in circular economy conditions, the waste management process is the most important. Among the various types of waste that must be managed, subsurface use wastes are distinguished generated in significant volumes during the operation of enterprises of the mineral resources sector.

Continuing to remain the basis for the sustainable development of the Russian economy as a whole, enterprises of the mineral resources sector cause serious environmental and economic damage, polluting the soil, air and water bodies [2]. An analysis of the data of the Federal Service for Supervision of Natural Resource Usage showed that the volume of generated waste production and consumption in the field of mineral extraction is on average $91.4 \%$ of the total volume of waste in the country. Over the past 9 years, it has more than doubled from 3334.6 million tons in 2010 to 6850.5 million tons in 2018 . The share of disposed and neutralized waste did not exceed $52.5 \%$ [3].

\footnotetext{
* Corresponding author: lyudmila.mochalova@m.ursmu.ru
} 
The large volume of waste generation and disposal in the field of subsurface use is explained, on the one hand, by industry specifics, in particular, the need for mining and overburden operations at mining enterprises, and, on the other hand, the lack of an integrated approach to the development of the mineral resource base.

The purpose of this article is to consider modern approaches to the subsurface waste management and to ensure the integrated development of the mineral resource base.

\section{Materials and Methods}

The complexity of organizing the effective waste management of the mineral resources sector enterprises lies in the need to take into account the environmental, industrial, technological and economic aspects of this issue and, accordingly, the application of interdisciplinary research methods.

When studying state reports on the state of the environment and reports on objects of accumulated environmental damage in Russia, it was found that the waste generated during mining, processing and transportation of rock mass accumulates in overburden and host rock dumps, tailings and sludge storages, forming man-made mineral formations (MMF). It should be noted that creation MMF is not only related to the activities of the enterprises of the mineral resources sector, including the totality of all mining and mineral processing enterprises (mining sector), but also the mineral resources base, and the exploration industry serving the mining sector. Their formation is possible with the functioning of the enterprises of the metallurgical, fuel and energy, military-industrial and chemical sectors.

At first glance, MMF only harm the environment and do not provide economic benefits. However, when researching the opinions of specialists and studying the economic aspects of the practical use of subsurface wastes, an assumption was made about the availability of industrial value of many MMF $[4,5]$. Thus, the currently available MMF, which will be proved that they are suitable for effective use in the field of material production in terms of the quantity and quality of the contained mineral raw materials, may be in the rank of manmade mineral deposits (MMD) ready for development.

From the point of view of evaluating the effectiveness of the technologies used, MMD formed during waste neutralization, storage and disposal should be considered as a result of using the least preferred methods of handling production and consumption waste [6]. In accordance with the data in Table 1, it can be seen that recycling (the use of waste for products manufacturing, including the reuse of waste) as the most preferred method of waste management in 2018 amounted only $52.33 \%$ by type of economic activity "Mining operation"; the remaining $47.67 \%$ of the waste went to neutralization (reduction of waste mass, change in composition, physical and chemical properties, including incineration and (or) disinfection in specialized facilities), storage (storage of waste in specialized facilities for more than 11 months for disposal, neutralization, depositing) and depositing (isolation of waste not subject to further disposal in special storage facilities).

Table 1. Volumes of production and consumption waste management in the Russian Federation by "Mining operation" type of economic activity in 2018 [3].

\begin{tabular}{|c|c|c|c|c|c|}
\hline & Formation & Disposal & Neutralization & Storage & Depositing \\
\hline $\begin{array}{c}\text { Volume, mlt } \\
\mathrm{t}\end{array}$ & 6850.5 & 3585.0 & 0.2 & 2372.1 & 893.2 \\
\hline $\begin{array}{c}\text { Share in } \\
\text { waste } \\
\text { production } \\
\text { volume, \% }\end{array}$ & 100 & 52.33 & 0.00 & 34.63 & 13.04 \\
\hline
\end{tabular}


To ensure efficient management of subsurface waste and ensure the integrated development of the mineral resources base, it is necessary to use modern management technologies based on the use of system and process approaches. Such technologies may include circular business models, 3R and 5R concepts, as well as logistics methods for waste management.

\section{Results and Discussion}

According to the authors of the article, in the context of the transition to a circular economy, it is advisable for modern subsurface use enterprises to use the circular business models proposed in the report [1]. For their successful practical development, the main environmental and economic goal of the enterprises of the mineral resources sector should be the transition to a closed-loop model based on the 3R concept: Reduce (reduction of waste generation), Reuse (waste reuse) and Recycle (recycling of waste into the state of secondary raw materials) [7]. This concept is presented in the Federal Law dated June 24, 1998 No. 89 in the form of such waste disposal methods as recycling (reuse of waste for its intended purpose), regeneration (returning waste to the production cycle after appropriate preparation) and recovery (recovery of useful components for their repeated use). In the future, it is possible to expand the concept to 5R by taking into account all stages of the product life cycle and adding two more Rs: Recover (restoration) and Redesign (redesigning). The sixth $\mathrm{R}$ with the definition Remanufacture (remanufacturing), presented in the well-known concept of $6 \mathrm{R}$ $[8,9]$, is not applicable to subsurface use waste.

According to the authors, even when implementing the 5R concept (Table 2), one can talk about a rather high degree of integrated use of mineral raw materials and solving about $90 \%$ of the problems associated with subsurface use waste.

Table 2. Subsurface waste management methods in accordance with the $5 \mathrm{R}$ concept.

\begin{tabular}{|l|l|l|}
\hline $\begin{array}{l}\text { Concept } \\
\text { definition }\end{array}$ & $\begin{array}{l}\text { Name of waste } \\
\text { management } \\
\text { method }\end{array}$ & $\begin{array}{l}\text { Examples of application of the waste management method in the } \\
\text { conditions of subsurface use }\end{array}$ \\
\hline Reduce & $\begin{array}{l}\text { Waste } \\
\text { production } \\
\text { reduction }\end{array}$ & $\begin{array}{l}\text { Use of overburden, tailings and sludges of the processing plant, industrial } \\
\text { water in the production of filling mixture to fill the worked out area. } \\
\text { Use of overburden for the reclamation of worked out area of open-pits. }\end{array}$ \\
\hline Reuse & $\begin{array}{l}\text { Reuse of waste } \\
\text { purpose }\end{array}$ & $\begin{array}{l}\text { Production and use of by-products (gravel, sand and gravel mixtures, heat- } \\
\text { insulating materials, stone-cutting products, etc.). } \\
\text { Use of mineralized drains in the leaching process for processing poor ores and } \\
\text { industrial wastes from mining, processing and metallurgical industries. } \\
\text { Formation of artificial reservoirs in the place of flooded quarry excavations } \\
\text { that are used for recreational purposes. }\end{array}$ \\
\hline Recycle & $\begin{array}{l}\text { Use of waste as } \\
\text { a secondary } \\
\text { raw material }\end{array}$ & $\begin{array}{l}\text { Use of overburden and tailings for the manufacture of construction materials. } \\
\text { Use of associated petroleum gas as a chemical and energy feedstock. } \\
\text { Development of man-made mineral deposits. } \\
\text { Recycling of sewage sludge and solids collected from dust and gas emissions: } \\
\text { from sewage sludge residues to obtain fertilizers and soil conditioner; from } \\
\text { captured inorganic substances (sludge) - artificial light substances used for the } \\
\text { production of construction materials, flower pots; from captured dust - such } \\
\text { useful components as zinc, aluminum, copper, iron, vanadium pentoxide, etc. }\end{array}$ \\
\hline Recover & Recovering & $\begin{array}{l}\text { Purification of mineralized wastewater, mine and groundwater for the purpose } \\
\text { of subsequent use as industrial water, for irrigation of crops or for return to the } \\
\text { hydrographic network (discharge of treated water into water bodies). }\end{array}$ \\
\hline Redesign & Redesigning & $\begin{array}{l}\text { Extraction of useful components from substandard and off-balance minerals } \\
\text { with the advent of new technologies or changes in conditions. } \\
\text { Organization of mining museums, cultural monuments, expositions at the site } \\
\text { of closed mining workshops, mines }\end{array}$ \\
\hline
\end{tabular}

Source: compiled by the authors based on $[10,11]$ and own observations 
When studying the logistics methods of waste management in relation to the mineral resources sector, the authors of the article found out the fact of their usefulness and, accordingly, received prove of the possibility of their use as secondary raw materials. At the mining enterprise, in addition to the main production flows, it is advisable to allocate material flows associated with subsurface waste $[12,13]$.

When considering material flows that go beyond the boundaries of the mining enterprise, the authors of the article have analyzed and evaluated the possibilities of subsurface waste management within the framework of established and potential industrial symbioses [14], which include, in addition to the subsurface use enterprise, a complex of consumer enterprises and waste processing enterprises. As actual and potential consumer enterprises, construction organizations, road repair and construction enterprises, road maintenance enterprises using associated products of a mining enterprise (for example, gravel, sand and gravel mixes, rubble stone, etc.) for their intended purpose were considered. Processing enterprises of subsurface use waste were represented by asphalt concrete plants, factories for the production of heat-insulating materials (HIM), water treatment plants, enterprises for the production of dry building mixtures, etc.

The systematic accounting of management technologies in the form of circular business models, 5R concept, and waste management logistics methods allowed the authors to develop an approximate structure of eco-industrial symbiosis (Fig. 1); the main object of which is a mining enterprise, including ore management, concentration plant, tailings and sludge depositaries, overburden and host rocks dump and associated with other objects of symbiosis by material flows.

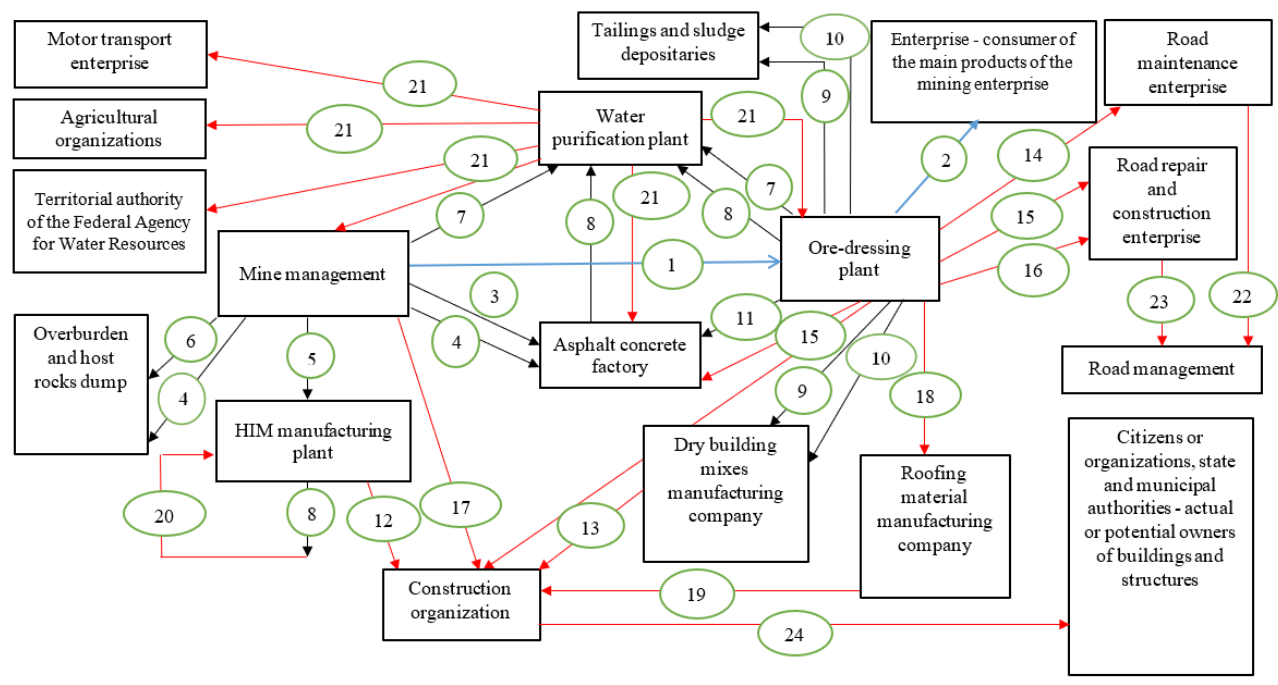

Fig.1. Interconnection of eco-industrial symbiosis objects through material flows.

Legend to Figure 1.

Numbers and names of flows 1-2 (main products of the mining enterprise divisions):

1 - ore

2 - sellable concentrate

Numbers and names of flows 3-11 (wastes):

3 - rock overburden

4 - enclosing rocks

5 - gabbro subsurface rock

6 - soft overburden

7 - mineralized waste discharges 
8 - contaminated water

9 - tailings

10 - sludges

11 - rock screening

Numbers and names of flows 12-24 (waste products and waste management services):

12 - heat-insulating materials

13 - dry building mixes

14 - anti-icing sprinkling (used as an anti-icing agent for sprinkling roads of all types)

15 - crushed stone (used in road construction; in the course of construction work; as a filler for monolithic, prefabricated and reinforced concrete structures)

16 - sand and crushed stone mixes (used for the arrangement of coatings, foundations and additional layers of the foundations of roads and airfields, to strengthen roadsides)

17 - quarry stone (used for laying foundations, external and internal walls; in the construction of hydraulic structures and other massive concrete and reinforced concrete structures; for decoration of buildings and structures)

18 - granite or stone screening - coarse-grained sprinkling (used in the manufacture of soft roofs for ruberoid armoring)

19 - soft roof for ruberoid armoring

20 - secondary use of contaminated water in a closed cycle

21 - purified water (used for the manufacture of filling mixtures and other industrial purposes; for irrigation of agricultural crops; for discharge into the hydrographic network (reservoirs))

22 - road maintenance services

23 - road construction and repair services

24 - services for the construction and repair of buildings and structures

\section{Conclusion}

1. In the transition to a circular economy, it is very important to organize the process of subsurface waste management, which makes up more than $90 \%$ of the total volume of waste in Russia.

2. To ensure effective waste management of enterprises of the mineral resources sector, it is necessary to take into account the environmental, industrial, technological and economic aspects of this issue.

3. In the field of subsurface waste management, it is advisable to use such modern management technologies as circular business models, 3R and 5R concepts, as well as logistics methods for waste management.

4. These technologies make it possible to form an eco-industrial symbiosis, the main object of which is a mining enterprise connected with other symbiosis objects by material flows.

5. Successful functioning of eco-industrial symbiosis should lead to the maximum use of subsurface waste, minimization of their storage and disposal volumes, and, ultimately, will contribute to the integrated use of mineral raw materials.

\section{Acknowledgments}

The reported study was funded by RFBR, project number 20-010-00305A. 


\section{References}

1. Ellen MacArthur Foundation: Towards a Circular Economy: Business Rationale For An Accelerated Transition, 2015,

2. L. A. Mochalova, Gornyi Zhurnal, 1, 28 (2019)

3. State report "On the condition and environmental protection of the Russian Federation in 2018"

4. Geological report on the results of work on the topic: Systematization of materials for technogenic deposits (formations) - waste from mining, processing, metallurgical, chemical and energy industries in order to replenish their data bank, to improve the certification system and automated accounting" for 1997-2001.

5. A. B. Makarov, Bulletin of the Ural State Mining and Geological Academy, 18, 158 (2003)

6. The Federal Law "On Production and Consumption Wastes" dated June 24, 1998, No. 89-Ф3.

7. Reduce Reuse, and Recycle Concept (the 3Rs") and Life-cycle Economy / Governing Council of the United Nations Environment Programme. 2005. UNEP/GC.23/INF/11. URL: wedocs.unep.org/rest/bitstreams/45276/retrieve

8. A. Houshyar, R. Sulaiman, Journal of Applied Environmental and Biological Sciences, 4(4), 7 (2014)

9. D. V. Valko, Scientific journal NRU ITMO. Series "Economics and Ecological Management", 2, 42 (2019)

10. Waste management - problems, solutions: analytical review (Federal State Budgetary Scientific Institution "Scientific Research Institute, 2015)

11. V. I. Petukhov, Integrated sustainable waste management. Mining industry: textbook, 638 (2016)

12. L. Mochalova, O. Sokolova, V. Yurak, Journal of Environmental Management and Tourism, 10 (1), 202 (2019)

13. V. A. Yukov, Mining Information and Analytical Bulletin, 10, 145 (2013)

14. Andreas M. Hein, Marija Jankovic, Romain Farel, Bernard Yannou, Proceedings of the ASME 2015 International Design Engineering Technical Conferences \& Computers and Information in Engineering Conference, (2015) 